\title{
UNDERSTANDING SUSTAINABILITY DNA: AN EXPLORATION INTO THE DNA OF THE TOP 100 SUSTAINABLE COMPANIES
}

\author{
Victoria L. Crittenden, Boston College, USA \\ William F. Crittenden, Northeastern University, USA \\ Evan Campbell, Boston College, USA
}

\begin{abstract}
Metaphorically, a company's tendency toward sustainability is a result of its DNA. That is, there are properties that trigger or shape sustainability activities within the organization. The company DNA holds the deeply rooted set of values and beliefs that provide behavioral norms that trigger or shape sustainability activities. Crittenden et al. (2011) identified three properties within a company's sustainability DNA: core ideology, dynamic capabilities, and societal engagement. Collins and Porras (1996) proclaimed that a company's core ideology was the glue that held the company together - the enduring character of the organization. Trice and Beyer (1993, p. 33) defined organizational ideology as the "shared, relatively coherent interrelated sets of emotionally charged beliefs, values and norms that bind some people together and help them make sense of their worlds." Since the core ideology does not change continually, the company's sustainability efforts must fit clearly within the domain of the company's purpose and values. Thus, according to Crittenden et al. (2011), the company's core ideology is exemplified by its mission and shared values. Day (1994) refers to organizational capabilities as complex bundles that are deeply embedded in organizational routines. Schreyögg and Kliesch-Eberl (2007) refer to these organizational capabilities as dynamic capabilities which are complex processes across an organization that can be built in different fields and at different levels of organizational activity. As such, Crittenden et al. (2011) propose that sustainable products are more likely to come from companies purporting to be integrated cross-functionally and that value collaboration internally and externally. Societal engagement involves the proactive development of strategies that benefit stakeholders and the organization. The supposition is that a firm's DNA has an embedded awareness of both societal issues and opportunities to create societal benefits as organizational resources are deployed for competitive advantage.
\end{abstract}

Given this initial exploration into the sustainability DNA, the decision was made to focus on companies that have a strong sustainability reputation. Corporate Knights (2012), a Toronto-based media, research, and financial products corporation, along with three partners, identify the 100 most sustainable companies in the world on an annual basis. This Global 100 has been released for 2012, and companies on this list are used for the data set in the current research. Thus, the websites for the 100 companies on the list were examined with the following content search guiding the exploration:

- Company mission, core values (i.e., core ideology DNA property )

- Cross-functional integration and supply chain collaboration in general or related to sustainability (i.e., dynamic capabilities DNA property)

- Community efforts and philanthropy (i.e., societal engagement DNA property)

The Global 100 companies are ranked from one to 100 via a rigorous sustainability assessment. In addition to pursing the identification of individual companies' sustainability DNA, the current research includes a country-by-country evaluation.

As noted in previous research, there is the need to understand why companies engage in sustainability. Crittenden et al. (2011) provided a theoretical framework for beginning to understand the underpinnings - the why - that companies do what they do. By offering the DNA construct and suggesting organizational properties of this construct, these authors provided an impetus for research into the why. However, there is a need to better understand the composition of the DNA properties before attempting to delineate testable variables. As such, this qualitative research project enables extensive exploration of sustainable companies' DNA. This review of the DNA properties will offer insight as to similarities/dissimilarities of DNA within a known group of sustainable organizations. If the content analytic method of websites appears to be a fruitful avenue, then the next step would be to identify a set of successful companies that are not on the Global 100 listing and compare their DNA properties to that found in this stage of the research.

References available upon request 